Language in Africa 2(1), 2021, 62-90. doi: 10.37892/2686-8946-2021-2-1-62-90

\title{
LINGUISTIC ASPECTS OF THE FORMS OF ADDRESS IN NYAKYUSA
}

\author{
Amani Lusekelo \\ University of Dar es Salaam \\ alusekelo@duce.ac.tz
}

Abstract: The main contribution of this article revolves around the choice of address forms as a mechanism to express politeness in an institutionalised setting in African context. To achieve this goal, I worked with spoken texts which enabled to unravel three issues. First, maternal forms of address in Nyakyusa reveal a dichotomy of male-female distinction, which adopts the male-oriented terms when the general population is referred to. Terms of masculine status are preferred in addressing the general public. In this case both male and female members of the community are addressed by male-oriented kin terms. Second, since utility of address forms primarily involves selection of kinship terms, their choice is a strategy employed to express politeness in face-to-face conversations. The extensions and incorporation of kinship terms in the forms of address is a testimony that the Nyakyusa people manoeuvres terms to express politeness. Lastly, Nyakyusa people have adjusted their kin system. This is obvious with such terms as usangasi (< Swahili: shangazi 'father's sister'), ugwifi (< Swahili: wifi 'brother's wife') and abalongosi (< Swahili: viongozi 'leaders'). In this regard, findings show that the lexicon for the traditional leadership is slightly disrupted by the introduction of the modern system of government.

Key words: Bantu, forms of address, gender, Nyakyusa, Tanzania

\section{Introduction}

The purpose of this article is to unravel the way the Nyakyusa (Bantu language spoken in Malawi and Tanzania) people ${ }^{1}$ express politeness

${ }^{1}$ Nyakyusa people inhabit the Nyasa-Tanganyika corridor (Wilson 1958; Walsh \& Swilla 2001). It is classified as M31 in the Guthrie's affiliations of Bantu languages (Hammarström 2019). According to LoT (2009: 2), there are 733,020 speakers 
in their face-to-face conversations. I take forms of address used in local meetings, family gatherings, and conversations of friends as kinds of institutionalised settings (Watts 2003). In the analysis of the datasets, therefore, I invoke the guidelines available in the theory of politeness in communication (Brown \& Levinson 1978; Watts 2003). I further approach the datasets with the assumption that speakers pay attention to the age differences (i.e. elders vs. young ones), cultural background (in formal and informal gatherings), sex orientation of the addressees, and social status of the interlocutors when they choose some structures, in this case address forms (Watts 2003). The specific intent is to explore the choice of the address forms in addressing members of the larger community in a formal meeting, immediate members in the family, and friends.

Two kinds of modes of address are commonly discussed in the existing literature, namely "address forms" and "kinship terms" (see Akindele 2008; Benjamin \& Afful 2007; Kawira 2014; Mashiri 2003; Miller 2016, among others). Technically, kinship terms split twice as per gender, namely masculine kinship terms and feminine kin forms (Burton \& Kirk 1976; Forde 1933; Miller 2016). But such kinship terms can be innovated so as to refer to another person. In this way, the kinship terms could be employed as address forms. Moghaddam et al. (2013: 56) accept that "address terms refer to the linguistic expression by which a speaker designates an addressee in a face-to-face encounter." Moghaddam et al. (2013: 58) accept that "teknonyms: nominal forms of address which define an addressee as a father, a brother, a wife, or a daughter of someone else by expressing the addressee's relation to another person."

In their analysis of kinship terms in Kimeru (Bantu) (Kawira 2014) and Hadzabe (Khoisan/Isolate) (Miller 2016), the essential display is the cognitive classifications of these forms on the basis of genealogical descent (e.g. grand-parents to grand-children), unilineal classification

of Nyakyusa in Tanzania. Felberg (1996) estimated some 300,000 speakers of Nyakyusa-Konde in Malawi. 
(i.e. patrilineal and matrilineal relations), and affine kinship which emanate from marriage. Irrespective of such detailed differences, Miller (2016) presents kinship terms which are generally divided into maternal (ancestry) and affinal (marital) systems. In another analysis of kinship terms, Murdock (1970) finds that languages display some patterns of kinship terms. Bantu languages exhibit cognates of kinship terms such as cross-cousins in Southern Bantu (Hammond-Tooke 2004).

Given the foregoing discussion, the current article brings to surface three claims. Firstly, the article addresses the sociological facts that come into play when a speaker uses an address form in a conversation, which in turn creates proper environment of interpretation of social relationship (Brown \& Levinson 1978). Put in other words, the choice of one address form rather than another form is determined by the cultural-based parameters (Watts 2003). In the course of presentation in this article, tokens of spontaneous conversations are used to unravel the functions of the address forms in the Nyakyusa society. In the course of the discussion of facts, I show that age and sex play an important part in the choice of the address forms in Nyakyusa.

Secondly, as opposed to personal names which bear less personal attitude, forms of address constitute a distinct pattern of socio-cultural interaction between members of a certain community. This phenomenon is cherished in conversations in African settings. According to Akindele (2008: 3), "terms of address are important linguistic mechanisms by which a speaker's attitude toward, and interpretation of his or her relationship with, a speaker is reflected. Inappropriate choice of the address hinders good communication between the speaker and the hearer." Since personal names amongst the Nyakyusa have been analysed by Lusekelo (2018), it remains necessary to investigate the usage of the forms of address in relation to personal names.

Thirdly, the presence of technical words which represent kinship terms and modes of address are a commonplace in African languages (Akindele 2008; Mashiri 1999). The evidence of their nativity hinges on their traceability to the Proto-Bantu forms (Bostoen 2019; Mark et al. 2015). Nonetheless, penetration of new words from Swahili into 
Bantu languages is a common phenomenon in Tanzania (see Mapunda \& Rosendal 2015; Swilla 2008; Yoneda 2010, among many others). It follows, therefore, an expose of the kinship terms and modes of address, which have not been examined in Nyakyusa, will make a positive contribution to the research on this subject matter. On the other hand, irrespective of their traditional reference to blood-related persons from the same descend (Forde 1935), the use of kinship forms transcend to other forms of address used in non-kin contexts (Kraska-Szlenk 2009; Wołk 2009). However, change in meaning of the existing words is reported in numerous studies involved in contact linguistics (Lusekelo 2013). This ground warrants an investigation of the meaning of kinship terms and modes of address in Nyakyusa.

Furthermore, as a result of prolonged contact, Miller (2016) reports of the incorporation of Datooga (Nilotic) and Sukuma (Bantu) into the kinship terms of Hadzabe (Khoisan/Isolate). Likewise, Lusekelo (2019) found that prolonged contact yielded the incorporation of kinship terms from Sukuma (Bantu) into Datooga (Nilotic) in north-western Tanzania. The adaptation of forms of address due to colonization, westernization and urbanisation happened amongst the Shona in the city of Harare (Zimbabwe) (Mashiri 2003). It remains necessary to conduct research on forms of address in Nyakyusa in order to unravel whether there are influences of the major donor language of Tanzania, namely Swahili (Mous \& Qorro 2009; Yoneda 2010; Mapunda \& Rosendal 2015).

In sections that follow, I organise the article in this manner. I outline the methods used to gather datasets. In the section, I, too, provide some examples to allow readers to be aware of the datasets analysed in this article. Then I discuss address forms used in formal gatherings in Nyakyusa society. There are about 16 forms of address which are utilized by the speakers of Nyakyusa for traditional, governmental and religious (Christianity) meetings. In the next section, I present kinship terms for both maternal and affinal relations. In both maternal and affinal kinship system, there are 31 forms of address are used by family members. In the section, I also argue that some kinship terms, e.g. batata 'fathers' can be used without gender connotations. The discussion 
of the forms of address amongst friends is given in the subsequent section. This section is followed by a discussion of the entire data provided in the paper. The conclusion is in the last section.

\section{Methodology}

The linguistic materials presented in this paper were gathered through four methods. Firstly, tokens of forms of address were extracted from the narrations compiled by Bastian Persohn (Persohn 2017), Knut Felberg (Felberg 2004), SIL International (Mbeya, Tanzania) (SIL 2008), and my own field datasets. In my own datasets, spontaneous conversations remain the primary source of tokens of address forms. In examples (1)-(3) from Felberg (2004), I present sentences with these forms of address: unkasi 'wife', undume 'husband', unkiikulu 'wife, woman', malafyale 'king, chief' and bagwitu 'dear colleagues, relatives'. The choice of each of these terms is discussed in detail in the subsequent sections.

(1) Po u-n-kasi gw-ake a-li-n-lalusisy-e u-n-dume then AUG-1-wife 1-POSS SM1-PST-OM1-ask-PFV AUG-1-husband a-t-ile: u-twa-mu-nda tu-li kugu? SM1-say-PFV AUG-13.ASSOC-18-inside 13-be where U-n-dume a-t-ile: $\quad$ Gwe $n$-kasi gw-angu... AUG-1-husband SM1-say-PFV 2sG 1-wife 1-Poss 'Then his wife asked her husband. She said: Where are the inner parts (of meat)? Her husband replied. He said: My wife...'

(2) A-t-ile: $\quad$ n-kiikulu n-sumwik-e ku-ku-lond-a u-n-kiikulu SM1-say-PFv 1-woman sM1-go-IMP 17-FUT-search-FV AUG-1-woman 'He said: Wife, I am going to look for another woman...'

(3) Naloli ba-gwitu u-mu-ndu malafyale kuno i-ku-fum-a true 2-POsS AUG-1-person 1.king where SM1-PRS-come-FV 'It is true relatives! This man is a King in his place.' 
Secondly, as a mother-tongue speaker, I use introspective elicitation and spontaneous conversation in gathering the utility of address forms amongst the Nyakyusa people. On the one hand, during introspective elicitation, I focus on stories gathered with the help of one speaker. ${ }^{2}$ On the other hand, datasets were extracted from spontaneous conversations with speakers of Nyakyusa. In Rungwe district (Tanzania), I obtained numerous tokens of usage of the kinship terms. I participated in local meetings in Nkunga village where forms of address in Nyakyusa were gathered, as exemplified in (4). In this example which is an extract from a local meeting that occurred in Nkunga village, the family name Mwansombelo and kinship term batata 'elders' are used. This is an example of an institutionalised formal gathering in which the societal culture associated with greetings is respected. ${ }^{3}$

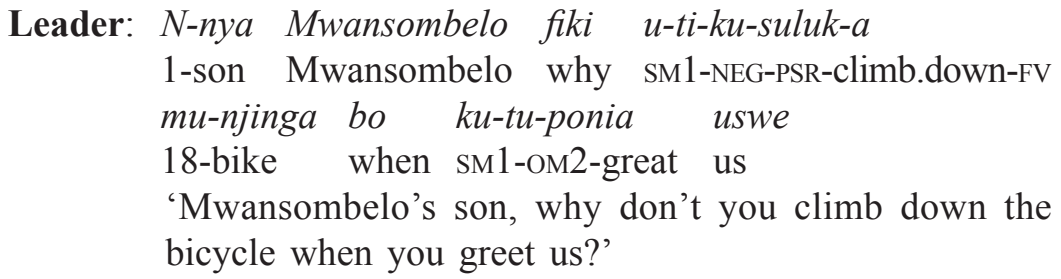

$\begin{array}{llll}\text { Jobu }^{4}: & \text { Mma } & \text { n-sob-ile } & \text { ba-tata } \\ & \text { no } & \text { SM1-loose-PFV } & \text { 2-father } \\ & \text { 'No! I have wronged you, my parents.' }\end{array}$

Thirdly, I managed to elicit the usage of the affinal and maternal kinship terms from three speakers of Nyakyusa ${ }^{5}$. Some of these kinship

${ }^{2}$ I am grateful to Enock Mwandambo for the discussion on forms of address amongst the Nyakyusa people of Rungwe district in Tanzania.

${ }^{3}$ In meeting the people in Nyakyusa society, the incoming person will be required to stop/stand and greet one another; usually holding hands, if possible (Walsh 1982).

${ }^{4}$ The first name of Mwansombelo's son is Jobu.

${ }^{5}$ The discussion with speakers of Nyakyusa was made possible under the auspices of BaSIS project hosted at Leiden University in The Netherlands. I am grateful to the Nyakyusa informants: Bahati Mwakasege, Peter Mwaipyana and 
terms are used in sayings, as illustrated in (5). In this example which is a text from casual spoken discourse, the address form nyoko 'mother' is used in a Nyakyusa saying/proverb.

(5)

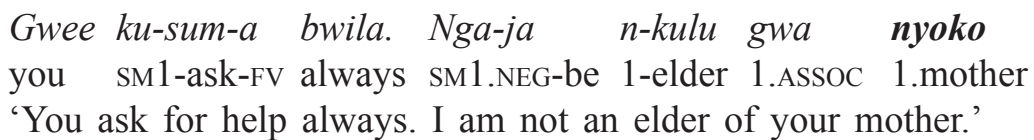

The last source of dataset is a Nyakyusa-English-Swahili dictionary compiled by Felberg (1996). Numerous kinship terms are listed in this book. In extracting the kinship terms, I used their equivalents from Swahili (Bantu) and English as the key point of identification of the address forms in Nyakyusa.

\section{Forms of address in formal gatherings: The power-over and power-to structures in politeness}

Formal gatherings, called ulukomano (in plural: ingomano) in Nyakyusa, concern meetings summoned by the traditional leaders of the village. After the introduction of Christianity, gatherings of church clergymen and congregations from many churches were also called ulukomano (ingomano) 'church meeting'. Today, the term involves governmental meetings called by elected political leaders or appointed leaders. In either of the meetings, forms of address used are common (Table 1).

Based on politeness theory, the usages of these terms indicate someone's power-to (make decision, induce punishment etc.) and powerover someone else. Watts (2003: 156) points out that in institutionalised forms of social interaction, "part of the objectified structures that an individual has internalised as her/his habitus is that certain participants also have power over others which will determine the politic behaviour

Yona Mwaipaja, as well as Jenneke van der Wal (Leiden University) and Simon Msovela (University of Dar es Salaam). 
Terms of address in formal gatherings in Nyakyusa

\begin{tabular}{|c|l|l|}
\hline S/N & $\begin{array}{c}\text { Terms of } \\
\text { address }\end{array}$ & \multicolumn{1}{|c|}{ Referents } \\
\hline 1 & malafyale & chief, king \\
\hline 2 & mfumu & chief's advisor \\
\hline 3 & benekisu & citizens in general \\
\hline 4 & batata & elders/parents \\
\hline 5 & bajuba & female elders \\
\hline 6 & bakipanga & members of a village/congregation \\
\hline 7 & undongosi & leader/head/spearhead \\
\hline 8 & ubalosi & ten-cell leader $(<$ Swahili: balozi 'representative') \\
\hline 9 & umwenyekiti & village leader (< Swahili: mwenyekiti 'chairperson') \\
\hline 10 & umbunge & MP (< Swahili: mbunge 'Member of Parliament') \\
\hline 11 & umpuuti & priest \\
\hline 12 & $\begin{array}{l}\text { unkulu gwa } \\
\text { kipanga }\end{array}$ & head of congregation/faction \\
\hline 13 & abadyakoni & deacons \\
\hline 14 & bagwitu & colleagues, relatives or fellow country-men \\
\hline 15 & bamama & 'elder mothers, female citizens' \\
\hline 16 & bababa & 'elder fathers, male citizens' \\
\hline
\end{tabular}

characterising the social interaction". One of the ways to express the social behaviour is through the choice of address forms.

In example (4) (\$2), the second speaker called Jobu, employs the address form batata 'my parents' as a referent to all people who gathered at that point. In this example, the address form batata is used to refer to the entire people available in the meeting. In this case, Jobu exhibits the behaviour that recognizes the status of the congregation, which could charge him if he continues to misbehave, even in the greeting pattern.

The leader of the gathering is complaining about the behaviour of Mwansombelo who did not show manners in the spoken discourse. The reality is that one cannot realize the whole set of Nyakyusa greeting 
while you are riding a bicycle. Walsh (1982: 33) points out correctly that "culturally the Wanyakyusa feel it impolite if the greeting ends with the two of you. It should start with the two and end with the whole families' or villages' welfare." Culturally, Jobu exhibited an impolite behaviour and the meeting had the power to charge him.

Another exemplary case is provided in (6), which come from an extract of a formal meeting in Nkunga village. In this case, Ipyana was summoned to a meeting to answer allegations of stealing a fowl. In his defense, he uses the address form benekisu 'country-men, citizens'. In this regard, he shows respect to the entire people involved on the meeting because they have power-to decide on his fate at that hearing.

(6)

$\begin{array}{llll}\text { Leader: } & \text { Gwee Ipyana ba-ti } & \text { gw-ib-ile } & \text { i-nguku } \\ \text { 1-son 1.Ipyana 2-say SM1-steal-PFV } & \text { AUG-fowl } \\ \text { 'You, Ipyana, it is said that you stole a chicken. } \\ \text { Ipyana: } & \text { Mwee bene-kisu } & \text { si-ka-ja sya } & \text { naloli } \\ & \text { you 2.ownwer-land SM8-NEG-be } & \text { 8.ASSOC true } \\ \text { 'Hello country-men, it is not true.' } & \end{array}$

In the formal gatherings, selection of a proper address form at a specific event is central in indication of politeness behaviour in Nyakyusa society. Now I turn to the usage of each of the address forms which have been provided in Table 1. Each of these terms reveals the power-over someone and power-to do something.

The traditional leadership of the Nyakyusa people was under the stewardship of the chief called malafyale. Anthropologists Charsley (1969) and Wilson (1963) describe the hereditary and expansionist chiefdom of the Nyakyusa people. Usually, sons inherited chieftain after the passing away of their fathers. In other instances, sons were supposed to go out and establish chieftainship of their own under the kusoka system. Both the paramount chief and other chiefs were addressed as malafyale. Traditionally each malafyale was advised by a team of male elders called mafumu (in singular mfumu). 
When addressing specific chief, the name umalafyale 'the chief' is used. Likewise, when addressing specific chiefs, the name abamalafyale is used. This morphological pattern applies to the board of advisers. Thus, when addressing a specific advisor, the name umfumu is used. Also, when addressing the specific advisors, the name amafumu is used. Now we may notice that the linguistic morphology of Nyakyusa names bear augments (also called pre-prefixes). The shape of the augment is technically a vowel (Lusekelo 2009), as commonly appearing in many Bantu languages spoken in Africa (De Blois 1970; Hyman \& Katamba 1993; Katamba 2003; Legère 2005). According to Persohn (2017), in some contexts, the augment is used to indicate specificity. This is the case of the addition of $u$ - on the nouns umalafyale 'chief' and umfumu 'advisor' and $a$ - on nouns abamalafyale 'chiefs' and amafumu 'advisors'. When the augment is inserted, the form of address may constitute known referent.

As it will be discussed in $\S 4$, the borrowed terms $u b a b a$ [ $<$ Swahili: baba] 'father' and umama [ $<$ Swahili: mama] 'mother' can be extended to refer to citizens or elders in a meeting. In this regard, the address forms bamama 'mothers' and bababa 'fathers' becomes more of terms used in formal gatherings, while ubaba 'father' and umama 'mother' remains as kinship terms. The power over and power to appears to unfold in the address forms bamama 'mothers' and bababa 'fathers' but does not manifest in the kinship terms ubaba 'father' and umama 'mother'.

The citizens of the traditional Nyakyusa land are referred to as benekisu 'owners of the land/country'. This form of address is composed of the possessive bene 'owner of' and kisu 'country/territory'. This term of address manifests in plural because citizens constitute the entire population. If it appears in singular, i.e. mwenekisu 'owner of the land/ country', then it has reference to the chief. Both forms of address may be attached with the augment to indicate specificity, i.e. abenekisu 'the citizens of Nyakyusa land' and umwenekisu 'the chief of the land/ country'.

In the literature (Wilson 1959; Charsley 1969), it is suggested that villagers in Nyakyusa-land used to practice local gatherings to deliberate 
numerous issues surrounding their wellbeing. Modes of address for these meetings differed though a sense of togetherness is reflected in terms such as bakipanga 'owners of the land, citizens', bakiisu 'owners of the land, citizens' and bagwitu 'my fellow citizens'. In the terms bakipanga and bakiisu, inhabitants of a given village or settlements are treated as the owners of the land while the label bagwitu embraces relationship of all the residents of a given village.

In formal traditional meetings, the mass attending the assembly is addressed as batata 'fathers' and bajuba 'mothers' by a single person speaking in the gathering. The singulative of these terms include tata 'father' and juba 'mother'. In the gathering, the term batata 'parents' may be used as a collective term for both males and females. The best translation of the generic term batata will be elders, which excludes young members of the community. Likewise, the term bajuba may have reference to female elders, which excludes children. Nonetheless, the expression bajuba 'mothers' cannot be used as a reference to the entire population. In the conversation, both batata 'parents' and bajuba 'mothers' can be replaced by the expression benekisu 'owners of the land/country', which encompasses both genders.

The address term bakipanga 'country men and women' is commonly used amongst the Nyakyusa. Traditionally, the term bakipanga was used to differentiate members from different chiefdoms. The introduction of Christianity religion, sometime around 1890s (Wilson 1963), adopted this term to refer to a group of congregation. Today the address term has reference to villagers from village X, say for example, abakipanga kya Mwankenja 'people from Mwankenja chiefdom'. Also, it has reference to a certain congregation, e.g. abakipanga kya Afyusisye 'Afyusisye's congregation'.

Modern system of government was introduced by the German Colonial Administrators since the 1890s (Charsley 1969; Wilson 1963). The chiefdom was later abolished after independence of Tanganyika. Some terms of address were adopted from Swahili. In Table 1, the term undongosi is provided. The notion of this term originates from the Swahili term kiongozi 'leader/administrator', which derives from 
ongoza 'to lead/to head'. The Nyakyusa adopted the verb longosya 'to lead/to head' which derives the noun undongosi 'the leader/the head'.

The other terms of address in Nyakyusa are recent loans from Swahili. The head of ten-cell administrative unit is called ubalosi $(<$ Swahili: balozi 'leader/representative'). The selected political leader of a village is called umwenyekiti ( $<$ Swahili: mwenyekiti 'chairperson'). The Member of Parliament for the Kyela and Rungwe electoral constituents are referred to as umbunge (in plural: ababunge) $(<$ Swahili: mbunge 'Member of Parliament').

The incorporation of Swahili terms of address for the many administrative positions is common in Tanzania. Swilla (2008) found such terms as umbunge 'Member of Parliament' and umbalosi 'ten-cell representative' in the Bantu language Chindali, spoken in the NyasaTanganyika corridor. Likewise, Mapunda \& Rosendal (2015) and Yoneda (2010) found many terms associated with modern government in Matengo and Ngoni, Bantu languages spoken in Ruvuma region of Tanzania. This phenomenon is not restricted to Bantu languages; rather it is attested even in Cushitic Iraqw (Mous \& Qorro 2009).

Christianity adopted two indigenous forms of address. First, the priest, who happens to be the head of a congregation, is addressed as umpuuti. This is a typical religious position opposed to divine leaders attested in many African societies. In Nyakyusa, the term utuuta has reference to a divine leader (Felberg 1996).

Second, the priest (umpuuti) is assisted by heads of congregations and church association generally called unkulu gwa kipanga 'head of congregation/faction', in plural abakulu ba fipanga 'leaders of congregations'. Other church clergymen are addressed as abadyakoni 'deacons'. This term appears to have been borrowed from the word deacons.

The presence of English terms is common in Nyakyusa. Previously, Swilla (2000) and Lusekelo (2014) found numerous nouns of English origin in Nyakyusa. As a result, both Nyakyusa and Chindali constitute at least three layers of nouns, namely, (i) indigenous nouns, (ii) English loans, and (iii) Swahili loans. In some cases, both English and Swahili terms co-exist for the same referent. 


\section{Forms of address in family: choice of polite structures as a strategy to establish equilibrium}

The Nyakyusa people bears strength of a person from the networks a person establishes within an extended family. Lusekelo (2018) elaborates the family names as key to establishing a clan. In this line, usage of address forms become central in enabling someone maintain family and clan network. This is not unique to Nyakyusa people rather it extends to other African societies.

The analysis in this section, therefore, depends on extracts from family discourses. I want to argue that limited power to and power over is expressed using kinship terms. But such kinship terms can be extrapolated to politeness interpretations. This is in line with Watts (2003: 248) who points out that although extracts from family conversation normally do not exhibit politeness, "certain utterances are still open to polite interpretation precisely because of the delicate balance of power relations during the interaction and the need in closeknit networks to achieve interpersonal equilibrium in the development of emergent networks."

In examples (1) and (2) (in §2), the forms of address used fall into family discourses. In the narrations, the terms nkasi 'wife', ndume 'husband' and nkiikulu 'woman' are used to express social relationships within the family. The Nyakyusa people appear to practice both paternal and maternal system (Iliffe 1979; Lusekelo 2018). The address forms for WIFE and HUSBAND are commonly used. But in example (2), the use of the term nkiikulu 'woman' for wife has indirect polite interpretation. Although the story involves wrong doing of the wife, the husband indicates respect for her by addressing her as nkiikulu 'wife'.

The presence of polite interpretation is family discourse is possible when family gatherings occur. This is indicated in example (7), which is an extract from case-hearing in one family. Mose was summoned by elderly women in the family to hear about his decision to hit his wife. 
(7) Head: Gwee Mwankina papo u-n-kom-ile u-n-kiikulu you Mwankina as SM1-om1-hit-PFV AUG-1-wife ku-n-homb-a i-ki-tenge

17-OM1-pay-FV AUG-7-wrap

'Mwankina, since you hit your wife, you are fined a wrap.'

Mose': Mma n-sob-ile juba.

no sm1-loose-PFV 1.mother

'No! I have wronged, my mother.'

Head: Gwee n-kiikulu po ku-ti bule?

you 1-wife then sm1-say what

'You, his wife, what do you say?'

In this text, the address form juba 'mother' has reference to respected woman in the family. Even though the addressee is not a biological mother of Mose, he addresses her with this title as she sits as the most elderly and respected person in that family meeting. Likewise, the address form nkiikulu 'woman' has reference to a specific wife of Mose. It is purposefully selected by the Head Woman in order to express her importance in the family of Mose.

Although usage of affinal kin terms is not directly associated with politeness (Watts 2003), I offered illustrations to show that their choice provides polite interpretation in Nyakyusa society. I now turn to the description of the affinal terms in Table 2 below.

In the Nyakyusa community, members of the community shy away from addressing each other using personal names. Thus, kinship terms constitute an important component of the forms of address within a family. Kin system divides into maternal (also called consanguineal) and affinal terms, as described below. The former refers to blood related family members, the latter has reference to spouses and in-laws (Miller 2016).

${ }^{6}$ The first and formal name of Mwankina is Mose, which is a loanword from Moses (Lusekelo 2018). Elders tend to address persons by the names of their grandparents. 
With regard to matrilinearity, amongst the Nyakyusa people of Tanzania, great-grand-parents, grand-parents, and parents are never addressed using their personal names by children. For instance, a child cannot call his or her parents (father and mother) by their personal names. The use of forms of address remains the main strategy utilised to indicate speaker's attitude towards parents.

Siblings, however, may refer to one another using personal names. This may involve siblings from one family or any other extended families. But general kinship terms of ukaka 'brother', udada 'sister' and ubinamu 'cousin' may be used. In Kyela and Rungwe districts of Tanzania, both elders and youngsters make use of these terms, but more specifically the terms $u k a k a$ 'brother' and udada 'sister'. These kinship terms are loans from Swahili.

Table 2 shows a couple of maternal kinship terms adopted in Nyakyusa language. Maternal kinship system goes far back to greatgrand-parents, commonly known as unyenya and great-grand-children referred to by the same name abanyenya (in plural). The following stage is that of grand-parents which are referred to by the term umwisukulu (in plural: abisukulu) for both brand-parents and grandchildren. The third layer include umpapi (in plural: abapapi), which has reference to both parents (mother and father). The fourth stage is composed of umwana-abaana 'child-children'.

Table 2

Maternal kinship terms in Nyakyusa

\begin{tabular}{|c|l|l|l|}
\hline S/N & Kin terms & Referents & \multicolumn{1}{|c|}{ Comments on status } \\
\hline 1 & unyenya & $\begin{array}{l}\text { great } \\
\text { grand- } \\
\text { parent/ } \\
\text { children }\end{array}$ & $\begin{array}{l}\text { It is gender neutral. The term abanyenya has } \\
\text { reference to both great-grand-parents and } \\
\text { great-grand-children. }\end{array}$ \\
\hline 2 & $\begin{array}{l}\text { umwi- } \\
\text { sukulu }\end{array}$ & $\begin{array}{l}\text { grand- } \\
\text { parent } \\
\text { and } \\
\text { grand- } \\
\text { children }\end{array}$ & $\begin{array}{l}\text { It is gender neutral. It has reference to grand- } \\
\text { parents and grand-children. }\end{array}$ \\
\hline
\end{tabular}


Continuation of Table 2

\begin{tabular}{|c|c|c|c|}
\hline $\mathbf{S} / \mathbf{N}$ & Kin terms & Referents & Comments on status \\
\hline 3 & abatata & \begin{tabular}{|l|}
$\begin{array}{l}\text { male } \\
\text { parent }\end{array}$ \\
\end{tabular} & $\begin{array}{l}\text { Traditional term that constitutes specific } \\
\text { reference to the general public/mass. }\end{array}$ \\
\hline 4 & $u b a b a$ & $\begin{array}{l}\text { male } \\
\text { parent }\end{array}$ & $\begin{array}{l}\text { It appears to be a new innovation that } \\
\text { replaced tata. Perhaps it is a loan from } \\
\text { Swahili (Swilla 2000). It has reference to } \\
\text { maternal father, father's brothers, father's } \\
\text { distant brothers and other male siblings in } \\
\text { father's family. }\end{array}$ \\
\hline 5 & uguso & $\begin{array}{l}\text { male } \\
\text { parent }\end{array}$ & $\begin{array}{l}\text { Your father (spoken by a second or third } \\
\text { party) }\end{array}$ \\
\hline 6 & abajuba & $\begin{array}{l}\text { female } \\
\text { parent }\end{array}$ & $\begin{array}{l}\text { Traditional term that constitutes specific } \\
\text { reference to group of women. }\end{array}$ \\
\hline 7 & uтата & $\begin{array}{l}\text { female } \\
\text { parent }\end{array}$ & $\begin{array}{l}\text { It appears to be a new innovation that } \\
\text { replaced juba. Again, probably it is Swahili } \\
\text { loanword (Swilla 2000). It used to address } \\
\text { maternal mother, mother's sisters, mother's } \\
\text { distant sisters and other female siblings in } \\
\text { mother's family. }\end{array}$ \\
\hline 8 & ukipapile & $\begin{array}{l}\text { female } \\
\text { parent }\end{array}$ & Endearing (attractive) term of address \\
\hline 9 & umwana & child & $\begin{array}{l}\text { It is the general term for male and female } \\
\text { children. }\end{array}$ \\
\hline 10 & unyoko & $\begin{array}{l}\text { female } \\
\text { parent }\end{array}$ & $\begin{array}{l}\text { Your mother (spoken by a second or third } \\
\text { party) }\end{array}$ \\
\hline 11 & umwana & child & It is for both masculine and feminine gender \\
\hline 12 & ubibi & $\begin{array}{l}\text { grand- } \\
\text { mother }\end{array}$ & $\begin{array}{l}\text { It is a Swahili loan which constitutes female } \\
\text { gender. }\end{array}$ \\
\hline 13 & ubabu & $\begin{array}{l}\text { gran- } \\
\text { dfather }\end{array}$ & $\begin{array}{l}\text { It is a Swahili loan which constitutes male } \\
\text { gender. }\end{array}$ \\
\hline 14 & ilumbu & $\begin{array}{l}\text { female } \\
\text { sibling }\end{array}$ & $\begin{array}{l}\text { It is being replaced by } d a d a \text {, which is a Swa- } \\
\text { hili loanword. }\end{array}$ \\
\hline 15 & unkulu & $\begin{array}{l}\text { male } \\
\text { sibling }\end{array}$ & $\begin{array}{l}\text { It is being replaced by kaka, which is another } \\
\text { typical Swahili loanword. }\end{array}$ \\
\hline 16 & unkulu & $\begin{array}{l}\text { elder } \\
\text { sibling }\end{array}$ & It is a kin term for elder sibling. \\
\hline
\end{tabular}


End of Table 2

\begin{tabular}{|c|l|l|l|}
\hline S/N & Kin terms & Referents & \multicolumn{1}{|c|}{ Comments on status } \\
\hline 17 & ubinamu & cousin & ( $<$ Swahili: binamu 'cousin') \\
\hline 18 & unyasenga & $\begin{array}{l}\text { father's } \\
\text { sister }\end{array}$ & - \\
\hline 19 & umwipwa & $\begin{array}{l}\text { 'mother's } \\
\text { bother' }\end{array}$ & - \\
\hline 20 & unnuguna & $\begin{array}{l}\text { young } \\
\text { sibling }\end{array}$ & - \\
\hline 21 & umujomba & $\begin{array}{l}\text { mother's } \\
\text { brother }\end{array}$ & (< Swahili: mjomba 'mother's brother') \\
\hline 22 & usangasi & $\begin{array}{l}\text { father's } \\
\text { sister }\end{array}$ & (< Swahili: shangazi 'father's brother') \\
\hline
\end{tabular}

Parents are addressed by two kinship term each. The first terms, juba 'mother' and tata 'father' are indigene. Alternative terms, the forms of address uguso 'your father' and unyoko 'your mother' are commonly used amongst the Nyakyusa. These terms are being substituted by the terms mama and baba which are commonly used in Swahili. The terms uguso 'your father' and unyoke 'your mother' are becoming derogatory.

It appears that "person" is an essential determinant of the choice of address terms for mother and father. The referents in the second and third persons utilize other address terms. In the second person, the expressions unyoko 'your mother' [abanyoko 'your mothers'] and uguso 'your father' [abaguso 'your fathers'] are used to refer to someone's mother and father respectively. In the third person, the terms for third person will be unemwe 'his/her mother' and ugwise 'his/her father' which are also used to refer to someone's mother and father respectively.

Siblings are addressed depending on their gender. Female siblings are called balumbu (in singular: ilumbu) by their male siblings, while male siblings are referred to as unkulu by female siblings. The kinship term unkulu is also used as a neutral name for elder brother and sister, while the term unnuguna is used for both young brother and sister. 
Father's sisters (both elder and young) are referred to as abanyasenga. This term is being replaced by usangasi $(<$ Swahili: shangazi 'father's sister'). The relative term umujomba ( $<$ Swahili: mjomba 'mother's brother') is now introduced amongst the speakers of Nyakyusa. Likewise, mother's sisters (both elder and young) are referred to as abipwa (in singular: umwipwa). This term is being replaced by umama ( $<$ Swahili: mama 'mother'). Elder mother's sisters are called umama unkulumba 'elder mother' and umama unnandi 'young mother'. This phenomenon is not unique to Nyakyusa; rather it is attested in Chindali (Swilla 2000; 2008), Chingoni (Mapunda \& Rosendal 2015), Matengo (Yoneda 2010), among other Bantu languages of Tanzania.

Table 3 displays affinal kinship system in Nyakyusa. Two important terms are undume (in plural: abalume) 'husband' and unkasi (in plural: abakasi). The former has reference to mother's brother in other Bantu languages, while the latter refers to women in many Bantu languages (Kuper 1979). Bostoen (2019) presents the proto-forms *kádi 'woman; wife' and *dómè 'male; husband; man' in Proto-Bantu. In Nyakyusa, these terms have been adopted to refer to wife and husband respectively.

The general term abanyambala 'men' is adopted as the reference to husbands. It is used by female siblings from the wife's descent. The term abakikulu 'women' is also adopted to refer to wives. It is used by male siblings from the husband's descent. In this regard, there is no way siblings from each descent may refer to their affinal relatives by personal names.

Generally, parents of wives and husbands are called as ubaba, utata 'father' and umama, ujuba 'mother'. The use of kinship terms umukwe 'parent-in-law' and unkamwana 'mother-in-law' constitutes gender differentiation. The former has reference to parent-in-law when used by sons-in-law, while the latter has to be used by daughters-in-law.

The notion brother's wife is generally referred to as unkikulu 'wife, woman' by both male and female siblings of the husband's descent. Language contact, however, have yielded integration of the notion ugwifi (< Swahili: wifi 'brother's wife'). Likewise, another loanwords usemeki reference to both sister-in-law and brother-in-law. 
Table 3

\section{Affinal kinship terms in Nyakyusa}

\begin{tabular}{|c|l|l|l|}
\hline S/N & Kin terms & Referents & Comments on status \\
\hline 1 & unkasi & wife & $\begin{array}{l}\text { Perhaps its root is abakasi, which has general } \\
\text { reference to women in Bantu languages. }\end{array}$ \\
\hline 2 & unkiikulu & wife & $\begin{array}{l}\text { Endearing form of address for wife. It is also } \\
\text { used by female siblings when addressing } \\
\text { their brother's wife and her female siblings. }\end{array}$ \\
\hline 3 & undume & husband & $\begin{array}{l}\text { In plural abalume 'husbands'. This terms } \\
\text { means mother's brother in many Bantu } \\
\text { languages (Kuper 1979; Lusekelo 2019) }\end{array}$ \\
\hline 5 & undamu & $\begin{array}{l}\text { brother- } \\
\text { in-law }\end{array}$ & $\begin{array}{l}\text { Mnambala affinal term used by male siblings. } \\
\text { is also used by female siblings when addres- } \\
\text { sing their sister's husband and his siblings. }\end{array}$ \\
\hline 6 & $\begin{array}{l}\text { unkam- } \\
\text { wana }\end{array}$ & $\begin{array}{l}\text { male } \\
\text { parent/ } \\
\text { daughter- } \\
\text { in-law }\end{array}$ & $\begin{array}{l}\text { It is a form of address for wives, not hus- } \\
\text { bands. It is also used to address fathers of } \\
\text { husbands. }\end{array}$ \\
\hline 7 & ugwifi & $\begin{array}{l}\text { sister- } \\
\text { in-law }\end{array}$ & $\begin{array}{l}\text { (< Swahili: wifi 'brother's wife). It is com- } \\
\text { monly used by female siblings. }\end{array}$ \\
\hline 8 & umukwe & $\begin{array}{l}\text { father- } \\
\text { in-law }\end{array}$ & $\begin{array}{l}\text { It refers to parent-in-law when used by } \\
\text { son-in-law. }\end{array}$ \\
\hline 9 & usemeki & $\begin{array}{l}\text { sister/ } \\
\text { brother- } \\
\text { in-law }\end{array}$ & $\begin{array}{l}\text { The address term semeki (< Swahili: } \\
\text { shemeji) has reference to both sister-in-law } \\
\text { and brother-in-law. }\end{array}$ \\
\hline
\end{tabular}

Using the avoidance system, the Nyakyusa call both the wife of a son and father-in-law as unkamwana 'wife of son; father of husband'. The avoidance system is masculine because the mother-in-law is addressed as umama 'mother'. The husband of a daughter is called umwana 'son' and his siblings are referred to as abaana 'children'.

The address form unkamwana bears two usages. On the one hand, it refers to 'wife of son'. This is used when parents refer to a woman who is a wife of their family member. On the other hand, the same 
expression has reference to 'father of husband' when used by a woman who is married in a given family. This term, therefore, bears both genders, namely, masculine 'father of husband' and feminine 'wife of son'. Linguistically, the term bears two words, namely, $n k a$ 'wife of' and mwana 'child'. The reference to 'father of husband' is an extension of the meaning that is linked to 'wife of son'.

\section{Terms of address amongst friends: Maintaining social networks}

In this section, I discuss the usage of terms of address between friends. First of all, forms of address in the context of friendship bear less politeness interpretation but rather indicate social relationships. Watts (2003: 29) argues correctly that "we can of course make a case for saying that even this type of social interaction has become institutionalised and is subject to some kind of interaction order and the conventions of politic behaviour." I discuss the issue of culturally bound selection of address forms between friends in Nyakyusa society.

Friendship is common amongst the Nyakyusa people. The use of personal names is common among friends. However, when a third party addresses a personal who befriend the other, some terms are preferred.

The address form umwinangu (in plural: abinangu) 'my friend(s)' is commonly used to refer to a friend. Apart from other address forms, in example (8), the specific address form umwinangu 'my friend' is used for the referent which is known to both interlocutors. In this regard, this address form is preferred in order to express friendship.

\begin{tabular}{|c|c|c|c|c|c|}
\hline -n-dume & $a-l i$ & $n-k u-m v$ & & Gwe & \\
\hline & 1 & & & & \\
\hline & & & & & $a$-t-ile \\
\hline 1-be 17-whe & & 1-say-PFV & & & SM1-say- \\
\hline
\end{tabular}

tu-tag-e a-ba-ana m-misi

SM2-throw-IMP AUG-2-child 18-6.water

'Her husband asked her: You, where is the child? She replied: My friend said that let us throw children into the river.' 
The kinship term ugwakikolo (in plural: abakikolo) 'relatives' is commonly used with reference to friendly relatives. In general, abakikolo 'relatives' has reference to people from the same descend, either from father's or mother's ancestry.

The form of address ummanyani (in plural: abamanyani) 'friends' is a common address for both male and female friends of the same sex. There is no possibility that people of different gender to be bamanyani 'friends'. This means that friendship in Nyakyusa community is gender sensitive. But when a male person befriends a female person, the notion kigane is adopted. This term can refer to sexually interested friends.

Age is another feature that unfolds in friendship terms of address in Nyakyusa. The term unnine (in plural: abanine) 'his/her friends' are adopted to refer to friends of the same age-cohort. This term is another testimony that friendship in Nyakyusa community is gender sensitive. Thus, when a male person befriends a female person of the same age, the notion kigane is adopted rather than unnine. This term also has to do with sexually interested friends.

\section{Discussions}

\subsection{Forms of societal hierarchy among the Nyakyusa}

The recognition of hierarchy is central in expression of politeness. The theory of politeness recognizes that societies reveal hierarchy as regards to age, sex, political position etc. (Watts 2003). In this article, I argue that attitude of speakers is revealed based on the choice of address forms.

The datasets provided in the preceding sections would require further analysis which is based on existing literature. The word abatata was traditionally employed to derive the meaning "elders" even in circumstances which involves blood related persons and non-kin relationships. In all the traditionally called meetings, the address form batata 'male elders' turns generic in the sense that it is used to address both male and female participants in a local meeting. Wilson (1959) 
found that the system of leadership of the Nyakyusa is technically controlled by males. The chieftain called malafyale 'king, prince, chief' always reigned by men who were assisted by male commoners (village leaders) as kinsmen called атаfити (Charsey 1967; Wilson 1959). It follows; therefore, the meetings were traditionally attended by malafyale as the convener, amafumu as prince's advisors and men. It is from these participants to which an address form batata 'elders' draws its reference.

When attention was to be drawn to female elders in a group, the address term bajuba 'female elders' is to be employed. Although the Nyakyusa are assumed to be patriarchal in nature, the power of feminine lineage is also central. Wilson $(1954 ; 1959)$ is sceptical of this characterization because marriage of the Nyakyusa was either in cattle for rich patrilineal clans or provision of labour by the poor groom's family to the family of the bride hence matrilineal system. Since the mothers are also powerful, the label bajuba draws attention in meetings.

With the growing modernisation and westernization, gender equality is given priority in Tanzania. Both men and women attend formal meetings. Thus, the address term for the elders of the villages turns to be batata na bajuba 'fathers and mothers of the village'. Despite the awareness of gender equality in Nyakyusa villages, the preference of the order male-and-female is reminiscent of the patrilineal nature of the community.

The elders are assumed to be parents who raised families of their own. Given this strong inclination to marriage and children within a family (Wilson 1959), the address term bapapi 'parents' is used to draw reference to the elders of the village. If a single person addresses a gathering, the expression bapapi bangu 'my parents' will be used to refer to both kin and non-kin relations.

Alternative terms of address for parents include bababa 'fathers' and bamama 'mothers'. While the word baba 'father' entails a blood paternal parent, mama 'mother' has reference to a blood maternal parent. Their use transcends to non-kin contexts such as a regular meeting attended by males, the participants will be addressed as bababa 'fathers' 
and another meeting attended by females, the participants will be addressed as bamama 'mothers'.

\subsection{Issues of language contact and change of forms of address}

Christianity penetrated into Nyakyusaland by 1890s with the German Missionaries in Rungwe area and British Missionaries in Rwangwa (Manow) (Charsley 1969; Swilla 2000; Wilson 1958). The priests obtained esteemed positions hence be addressed with respect as mpuuti 'priest' (Felberg 1996). The wife of a priest will be called as mama mpuuti 'mother of the priest', in long form nkasi gwa mpuuti 'wife of a priest' or in short $n k a$ mpuuti 'wife of a priest'. These are generic terms which are utilized to refer to church men and women whose position, spiritually of course, is assumed to be high. For a meeting of Christians, priests will be addressed as bapuuti 'priests'.

In Moravian Church, elders for each group will be called nkulu gwa kipanga 'head of a congregation'. The kinship term nkulu 'elder brother/sister' (Felberg 1996) is coined to involve heads of congregations. In a group, therefore, heads of congregations will be addressed as bakulu ba fipanga 'the heads of congregations'.

The impact of the national language Swahili is felt in Nyakyusaland. This is apparently evident in modes of address as well. Previously studies reported that Nyakyusa were affected by English words (Lusekelo 2014) rather than Swahili civilisation (Wilson 1958). The general term basee or bazee 'elders' is borrowed from Swahili word mzee 'old man'. It is used by youngsters when addressing a meeting summoned by villagers in Nyakyusaland.

An analysis of the penetration of Swahili words into Nyakyusa begins with the terms for father and mother which are central in bloodrelated kinship terms. The split between male and female parents is apparently attested for the generic terms in Eastern Bantu (Mark et al 2015). The words ujuuba 'mother' and utaata 'father' are indigene in Nyakyusa. However, Felberg (1996: 141) claims correctly that "the 
word mama (from Swahili) is nowadays replacing the Nyakyusa juuba." Findings indicated that the nouns ubaaba 'father' [ababaaba 'fathers'] and umama 'mother' [abamama 'mothers'] are frequently used by the youth. Therefore, the indigene generic terms ujuиba 'mother' [abajuba 'mothers'] and utaata 'father' [abataata 'fathers'] which are used mostly by elderly persons get eroded by the Kiswahili terms mama 'mother' and $b a b a$ 'father'.

Another kin term which is affected by Swahili words is paternal aunt and maternal uncle. The kinship terms unyasenga 'father's sister' and umwipwa 'mother's bother' were commonly used. Nowadays, the paternal auntie is frequently referred to as sangasi which is a Kiswahili loan [<shangazi: paternal aunt]. Likewise, the paternal uncle is referred to as mjomba, a typical Swahili loan [<mjomba: uncle].

The kinship term umwisukulu traditionally used to have referents to three kin: grandmother umwisukulu unkikuulu, grandfather: umwisukulu unyambala and grandchild umwisukulu. Although nowadays both paternal and maternal grandparents are referred to by similar terms, Kiswahili words have taken over. The generic terms ubiibi 'grandmother' [ $<$ Swahili: bibi 'grandmother'] and ubaabu 'grandfather' [ $<$ Swahili: babu 'grandfather'] are commonly used amongst Nyakyusa speakers.

Moreover, with grandparents, the possessive expressions may indicate close relations, e.g. ubiibi gwangu 'my grandmother' and ubaabu gwake 'his/her grandfather'. Likewise, the generic term mwisukulu 'grandchild' [abisukulu 'grandchildren'] is used to refer to grandchildren from both paternal and maternal lineage. Any effort to delineate paternity and maternity will make use of the labels kukikikuulu 'to the maternal relations' and kukinyambala 'to the paternal kin'.

\section{Conclusion}

This article discussed three issues. The first one concerns the choice of address forms to exhibit interlocutors' social status within the 
institutionalised settings. It has been shown that speakers of Nyakyusa choose purposefully address forms in formal meetings in the family and in villages at large. Apart from the prescribed address forms in formal gatherings which adhere to leadership hierarchy, I showed that address forms of kinship origin can be used to indicate power relationship between the addressor and addressee. Within the theory of politeness, therefore, usage of one address form rather than the other appears to help to reveal the behaviour of speakers.

The remaining two issues concerns Nyakyusa people. On the one hand, it presented the properties of kinship terms attested in Nyakyusa. These kinship terms can be used in family discourse with less polite interpretation. However, I large family meeting, social status of family members unfolds. The elders will eventually achieve high status and get addressed using formal address forms such as juba 'mother'. This will not require the addressee to be a biological other of the addressor. Rather her social status allows her to addressed as so.

It is articulated, on the other hand, that the impact of Swahili culture on the forms of address in Nyakyusa. As a result, the conclusions of the paper are two-fold. First, maternal forms of address in Nyakyusa reveal a dichotomy of male-female distinction, which adopts the maleoriented terms when the general population is referred to. This is the case of the term batata 'fathers/parents/senior citizens' being the preferred general address than bajuba 'mothers', which is specifically constitute referent to female (senior) citizens. Likewise, affinal forms of address splits into male-female dichotomy with accentuation of the male-terms. The use of kinship terms umukwe 'parent-in-law' and unkamwana 'mother-in-law' constitutes gender differentiation in that the former has reference to parent-in-law when used by sons-in-law, while the latter has to be used by daughters-in-law. Second, incorporation of kinship terms is a testimony that the Nyakyusa speaking people have adjusted their kin system. For example, introduction of usangasi (< Swahili: shangazi 'father's sister') and ugwifi ( $<$ Swahili: wifi 'brother's wife') has disrupted the traditional names for mother and wife. 


\section{Abbreviations}

1, 2, 3 etc. - Bantu noun classes $\mathrm{PFV}$ - perfective formative ASSOC - associative marker POSS - possessive AUG - augment or pre-prefix PRS - present tense formative FUT - future tense formative PST - past tense formative FV - default (final) vowel $\mathrm{SG}$ - singular IMP - imperative marker $1 \mathrm{SG}$ - first person singular $\mathrm{NEG}$ - negation marker $2 \mathrm{SG}$ - second person singular OM - object marker or prefix SM - subject (agreement) marker

\section{References}

Akindele, Dele Femi. 2008. Sesotho address forms. Linguistik Online 34(2). $3-15$.

Benjamin, Joseph \& Afful, Archibald. 2007. Address forms and variation among university students in Ghana. Nordic Journal of African Studies 16(2). 179-196.

Bostoen, Koen. 2019. Reconstructing Proto-Bantu. In Van de Velde, Mark \& Bostoen, Koen \& Nurse, Derek \& Philippson, Gérard (eds.), The Bantu languages, $2^{\text {nd }}$ edition, 308-334. New York: Routledge.

Brown, Penelope. \& Levinson, Stephen. 1978. Politeness: Some universals in language usage. Cambridge: Cambridge University Press.

Burton, Michael \& Kirk, Lorraine. 1976. Semantic reality of Bantu noun classes: The Kikuyu case. Studies in African Linguistics 7 (2). 157-174.

Charsley, Simon R. 1969. The princes of Nyakyusa. Nairobi: East African Publishing House.

De Blois, Kornelis F. 1970. The augment in the Bantu languages. Africana Linguistica 4. 87-165.

Felberg, Knut. 2004. Nyakyusa Stories. Available at http://www.nyakyusa. com/nyastory.htm (Accessed 2011-08-15.).

Felberg, Knut. 1996. Nyakyusa-English-Swahili \& English-Nyakyusa dictionary. Dar es Salaam: Mkuki na Nyota.

Forde, C. Daryll. 1939. Kinship in Umor: Double unilateral organization in a Semi-Bantu society. American Anthropologist 41(4). 523-553. 
Hammarström, Harald. 2019. An inventory of Bantu languages In Van de Velde, Mark \& Bostoen, Koen \& Nurse, Derek \& Philippson, Gérard (eds.), The Bantu languages, $2^{\text {nd }}$ edition, 17-78. New York: Routledge.

Hammond-Tooke, W. D. 2004. Southern Bantu origins: light from kinship terminology. Southern African Humanities 16. 71-78.

Hyman, Larry \& Katamba, Francis X. 1993. The augment in Luganda: Syntax or pragmatics? In Mchombo, Sam (ed.), Theoretical aspects of Bantu grammar, 209-256. Stanford: CSLI, Stanford University.

Iliffe, John. 1979. A modern history of Tanganyika. Cambridge: Cambridge University Press.

Kraska-Szlenk, Iwona. 2009. Emotional aspects of inversion in Swahili address terms. In Pawlak, Nina (ed.), Codes and rituals of emotions in Asian and African cultures, 110-127. Warszawa: Dom Wydawniczy Elipsa.

Kawira, J. Flora. 2014. A semantic analysis of Kimeru kinship terms. Nairobi: University of Nairobi. (M.A. thesis.)

Kuper, Adam. 1979. Zulu kinship terminology over a century. Journal of Anthropological Research 35(3). 373-386.

Legère, Karsten. 2005. Pre-prefix or not - that is the question: The case of Kwangali, Kwanyama and Ndonga. In Voeltz, Erhard F. K. (ed.). Studies in African linguistic typology, 251-262. Amsterdam - Philadelphia: John Benjamins.

LoT (Language of Tanzania). 2009. Atlasi ya lugha za Tanzania [Atlas of the languages of Tanzania]. Dar es Salaam: University of Dar es Salaam.

Lusekelo, Amani. 2013. Swahili loanwords nativisations in the languages of Tanzania. Huria Journal of the Open University of Tanzania 14. 151162.

Lusekelo, Amani. 2009. The structure of the Nyakyusa noun phrase. Nordic Journal of African Studies 18(4). 305-331.

Lusekelo, Amani. 2014. 'Similar' languages contact, but 'different' languages change: Historical lessons from loanwords in Tanzanian Bantu communities. Journal of Education, Humanities and Sciences 3(1\&2). 91-110.

Lusekelo, Amani. 2018. An account of intercultural contact in Nyakyusa personal names. African Study Monographs 39(2). 47-67. 
Lusekelo, Amani. 2019. Adaptation of Sukuma loanwords in the western dialects of Datooga (Taturu) and its dialectological implications. Ethnologia Actualis 19(1). 54-89.

Mark, Jeff \& Hage, Per \& Bostoen, Koen \& Kamba-Muzenga, Jean G. 2015. Tin terms in the East Bantu: Initial findings. In Jones, Doug \& Milicic, Bojka (eds.), Kinship language and prehistory: Per Hage and the renaissance in kinship studies, 79-82. Utah: The University of Utah Press.

Mashiri, Pedzisai. 1999. Terms of address in Shona: A sociolinguistic approach. Zambezia 26(1). 93-110.

Mashiri, Pedzisai. 2003. A socio-linguistic interpretation of the social meanings of kinship terms in Shona urban interactions. Zambezia 30(2). 204-228.

Miller, Kirk. 2016. Hadza kinship terms. In Shenah, Shah \& Brenzinger, Matthias (eds.), Khoisan languages and linguistics: Proceedings of the $5^{\text {th }}$ international symposium, 277-333. Cologne: Ruediger Koeppe Verlag. Moghaddam, Azadeh Sharifi \& Yazdanpanah, Leyla \& Abolhassanizadeh, Vahideh. 2013. The analysis of Persian address terms based on the theory of politeness. SKASE Journal of Theoretical Linguistics 10(3). $55-71$.

Mous, Maarten \& Qorro, Martha. 2009. Loanwords in Iraqw, a Cushitic language of Tanzania. In Haspelmath, Martin \& Tadmor, Uri (eds.), Loanwords in the world's languages: A comparative handbook, 103123. Berlin: Mouton de Gruyter.

Murdock, George P. 1970. Kin term patterns and their distribution. Ethnology 9. 165-207.

Persohn, Bastian. 2017. The verb in Nyakyusa: A focus on tense, aspect and modality. Berlin: Language Science Press.

SIL 2008. Akapango ka Kalulu ni Sofu ni Fubu/Tujimikege injobelo jiitu ijaa KiNyakyusa [The story of the Hare and Elephant and Hippo / Let us praise our Kinyakyusa language]. Mbeya: SIL International.

Swilla, Imani N. 2000. Borrowing in Chindali. In Kahigi, Kuikoyela K. \& Kihore, Yared M. \& Mous, Marteen (eds.), Languages of Tanzania, 297-307. Leiden: Research for Asian, African and Amerindian Studies.

Swilla, Imani N. 2008. Signs of language shift in Chindali and the impact of Swahili. Language Matters 39(2). 230-241. 
Walsh, Martin. 1982. Nyakyusa greetings. The Cambridge Journal of Anthropology 7(3). 31-44.

Walsh, Martin T. \& Swilla, Imani N. 2001. Linguistics in the corridor: A review of the research on the Bantu languages of South-West Tanzania, North-east Zambia and North Malawi. Journal of Asian and African Studies 61. 275-302.

Watts, Richard J. 2003. Politeness. Cambridge: Cambridge University Press. Wilson, Monica. 1954. Nyakyusa ritual and symbolism. American Anthropologists 56. 228-241.

Wilson, Monica. 1958. The peoples of the Nyasa-Tanganyika corridor. Cape Town: University of Cape Town.

Wilson, Monica. 1959. The communal rituals of the Nyakyusa. London: Oxford University Press.

Wilson, Monica. 1963. Good company. A study of Nyakyusa age-villages. Boston: Beacon Press.

Wołk, Ewa. 2009. Positive and negative emotions encoded in Amharic forms of address. In Pawlak, Nina (ed.), Codes and rituals of emotions in Asian and African cultures, 128-136. Warszawa: Dom Wydawniczy Elipsa.

Yoneda, Nebuko. 2010. "Swahilization" of ethnic languages in Tanzania: The case of Matengo. African Study Monographs 31(3). 139-148. 